\title{
OBSTACLES TO THE EMPLOYMENT OF THE PERSONS WITH DISABILITIES FROM THE EMPLOYER'S PERSPECTIVE
}

\section{PREPREKE PRI ZAPOŠLJAVANJU OSOBA SA INVALIDITETOM IZ PERSPEKTIVE POSLODAVCA}

\author{
Paušić Vesna ${ }^{1}$, Krstić Tatjana ${ }^{2}$, Vidojević Jelena ${ }^{3}$ \\ ${ }^{1}$ Faculty of Medicine Novi Sad, University of Novi Sad \\ Hajduk Veljkova 3, 21000 Novi Sad, Serbia \\ ${ }^{2}$ Faculty of Medicine Novi Sad, University of Novi Sad \\ ${ }^{3}$ JPU 'Dječiji vrtić" Gacko, 89240 Gacko, BiH
}

Original Scientific Article

\begin{abstract}
The role of employers in obtaining a job for people with disabilities can be crucial. The law on "Professional rehabilitation and employment of people with disabilities" was supposed to be a key factor in improving the position of this population in the labor market, but in practice this has not been confirmed. One of the major obstacles to the employment of persons with disabilities is the lack of a register of persons with disabilities where employers colud find potential candidates with appropriate skills and competencies. This research was conducted with the aim of identifying potential barriers to employment of persons with disabilities perceived from the perspective of employers. The sample consisted of 50 employers of both state and private companies in the city of Novi Sad. Employers were surveyed with a questionnaire created for the purposes of this research, modeled on the Employers' Motivation Questionnaire for Employment of Persons with Disabilities with the prior consent of the author. The results schow that the adaptation of the workplace and access to means of transport are the biggest obstacle when we are talking about employing people with disabilities. In order to gain a deeper insight into the perspective of employers regarding the employment of people with disabilities, it is important to take into account their direct experiences as well as what worries them and what they feel insufficiently competent when it comes to employing this population.
\end{abstract}

Key words: people with disabilities, employers, barriers.

${ }^{1}$ Correspondence to:

Paušić Vesna, Faculty of Medicine Novi Sad, University of Novi Sad

E-mail: vesnampausic@gmail.com 


\section{INTRODUCTION}

The role of employers in obtaining, adjusting and retaining jobs for people with disabilities can be crucial. One of the most significant contributions in solving the high unemployment rate of persons with disabilities in Serbia is the adoption of the "Law on Professional Rehabilitation and Employment of Persons with Disabilities." This Law defines the rights, obligations and facilities of employers when employing persons with disabilities in order to increase the employment of this category of population. (Law on Professional Rehabilitation and Employment of Persons with Disabilities, 2009). Bearing in mind that the enactment of the "Law on Professional Rehabilitation and Employment of Persons with Disabilities" was one of the key factors aimed at improving the position of persons with disabilities in the labor market, previous research aimed at examining the employment rate of persons with disabilities shows a different picture. This is supported by the statement that during the first years of its implementation, the number of employed persons with disabilities increased by only 1\% (Cvejić, 2013). During a survey conducted by the Center for Independent Living of the Disabled of Serbia in 2010, it was found that the number of persons with disabilities among employees of surveyed employers is only $1.95 \%$, with most state-owned enterprises per hundred employees without a single person with disabilities ( Ljubinković et al., 2010). One of the major obstacles to the employment of people with disabilities is the lack of a register of people with disabilities where employers could find potential candidates with the appropriate skills and competencies. In some cities, there is a much greater need to employ this population than those registered with the National Employment Service. In such situations, employers are left with the payment of a fine due to insufficient employment of persons with disabilities (Cvitanović et al., 2015). The long-term exclusion of persons with disabilities from the regular education system has resulted in the perpetuation of widespread prejudices about their poor work potential, in addition to the low level of education of this population. Among the large number of employers today, unfortunately, is still always generally accepted opinion that members of this population can not achieve the required level of productivity, do not have developed work habits to a sufficient extent, due to their health condition will often be absent from work compared to the population of workers without disabilities (Lakićević, 2012). In addition, employers often want a person with a disability who does not have a visible disability to avoid the costs of job adaptation and fear that business partners and clients will react to the fact that the company employs a person with a visible form of disability (Dimitrijević, 2016). Employers may also consider persons with disabilities as a burden on the enterprise (Kaye et al., 2011), and accordingly they are afraid of their reduced productivity, ie their work incompetence (Kiš-Glavaš i Skočiš-Mihić, 2010). Employers believe that the nature of work tasks is such that people with disabilities would not be able to do them effectively even with adaptation (Houtenville and Kalargyrou, 2012). Employers also worry about the cost of employing this population, and consider job adaptation a great financial burden, especially if it is a significant adjustment of the job. 
In addition, they are concerned about additional health insurance costs, as well as indirect costs such as enhanced supervision (Boni-Saenz et al., 2006). The basis for the development of positive attitudes of employers towards the employment of persons with disabilities lies in the experience of the employment of this population (Nota at al., 2013). Research by Gilbride et al. (2003) (Gilbride et al., 2003) showed that employers who already have experience in employing workers from marginalized groups have a positive attitude towards employment and people with disabilities, and as a reason they state that they consider disability differently. According to research by other authors, employers who have a close friend or member with a disability in their or their extended family are more likely to employ a person with a disability than employers who do not have such experience, which speaks in favor of the importance of direct contacts and the need for better acquaintance people with disabilities (Woodley and Metzger, 2012). The results of the research point to the exceptional importance of informing employers about the possibilities and abilities of persons with disabilities in order to alleviate or completely eliminate prejudices about the professional and work capacities of this population (Kiš-Glavaš i Skočiš Mihić, 2010).

The population of people with disabilities in economic terms is a very large source of labor, which still remains underutilized. Through many researches, their reduced employability has been noticed, which can be considered as a consequence of discrimination, negative attitudes and lack of information of employers. If we compare foreign and domestic research, we can see that this population has difficulty in establishing employment regardless of the country in which it is located (Žuvela, 2013). We can also say that the reasons for their non-employment are quite universal, such as possible slower performance of work tasks, costs of adjusting the working environment, inadequate education, safety at work, but also difficulties in dismissing an employee whose productivity is not satisfactory. In the developed world, there are numerous studies on the role of employers in the employment of people with disabilities (Yang at al., 1986). Similar research in our country is extremely rare, so the purpose of this paper was to examine what employers accurately perceive and see as difficulties in the potential employment of this part of the population.

\section{MATERIALS AND METHODS Sample}

The sample consisted of 50 employers from state and private companies in the city of Novi Sad. The research was conducted during 2019. in the Public City Transport Company of Novi Sad, the Association of Paraplegics of the South Bačka District, the organization of the Multiple Sclerosis Society of Serbia, the company for production and wholesale of paints, varnishes and additives Vageli DOO, the Public Utility Company Tržnica Novi Sad and forty-five private companies. 


\section{Design and procedure}

Initial contact with the employers of these companies was established by telephone. On that occasion, the goal of the research was presented to them, and the date of the survey was agreed with those who agreed to participate in the research. Individual completion of the questionnaire took 5 to 15 minutes, depending on the need of employers for additional explanations or comments.

\section{Instrument}

The questionnaire for employers was created for the purposes of this research and consists of a total of 7 questions, of which 6 are closed-ended, to which respondents answered by circling one or more answers, and one open-ended question where employers briefly described their work experiences. with persons with disabilities. The questionnaire was created based on the Questionnaire of Employers' Motivation for Employment of Persons with Disabilities with the prior consent of the author (Kiš-Glavaš, 2003).

\section{Statistical analysis}

Descriptive statistics were used to analyze the obtained data.

\section{RESULTS AND DISCUSSION}

Of the total number of surveyed employers who participated in our survey on the question "Do you think that people with disabilities have the opportunity to progress in the workplace?" $80 \%$ of them answered yes, while $20 \%$ of respondents thought the opposite.

However, to the question "Have you ever employed people with disabilities in your company?" $73 \%$ of surveyed employers in the survey stated that they did not employ people with disabilities in their company, and only $27 \%$ of employers did so. Experiences of working with people with disabilities are positive in $27 \%$ of cases.

When we talk about the interest of employers in employing people with disabilities, the results show that $73 \%$ of employers included in our survey are interested in hiring a person with disabilities, while $27 \%$ are not.

Regarding the possibility of employers to employ a person with a disability in their company, the results show that only $27 \%$ of surveyed employers have the opportunity to employ a person with a disability in the company, while $73 \%$ believe that such an option does not exist. Regarding the necessary additional information on jobs that people with disabilities can work on, $60 \%$ of the surveyed employers gave a positive answer, and $40 \%$ a negative one. 


\section{What difficulties do you expect when hiring people with disabilities?}

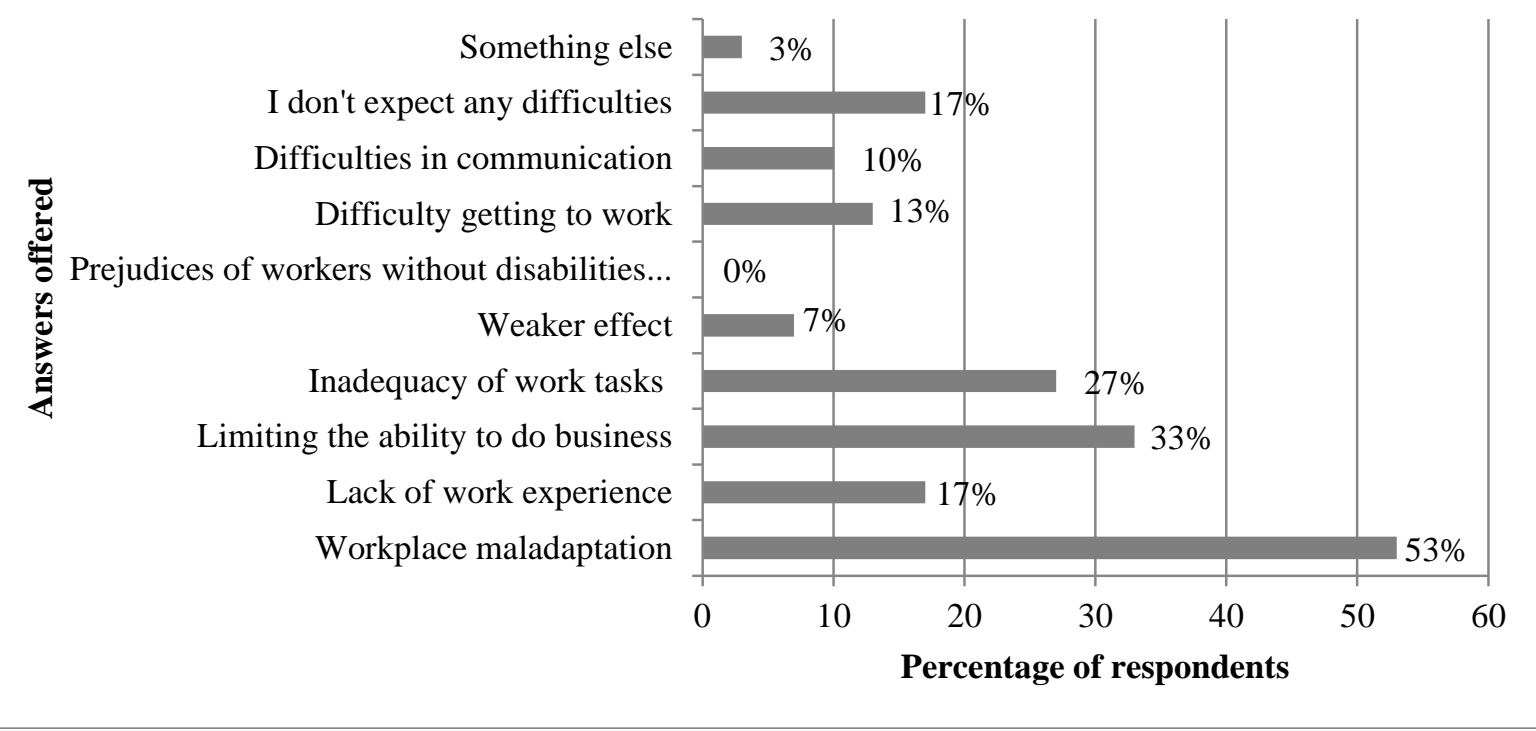

Graph 1. Expected difficulties in employing persons with disabilities perceived by the employer

From Chart 1 we can see that employers in the highest percentage (53\%) expect difficulties in unadapted workplace, then $33 \%$ of employers state the limitation of the possibility of work by people with disabilities, and $27 \%$ of employers see difficulties in unadapted work tasks. 


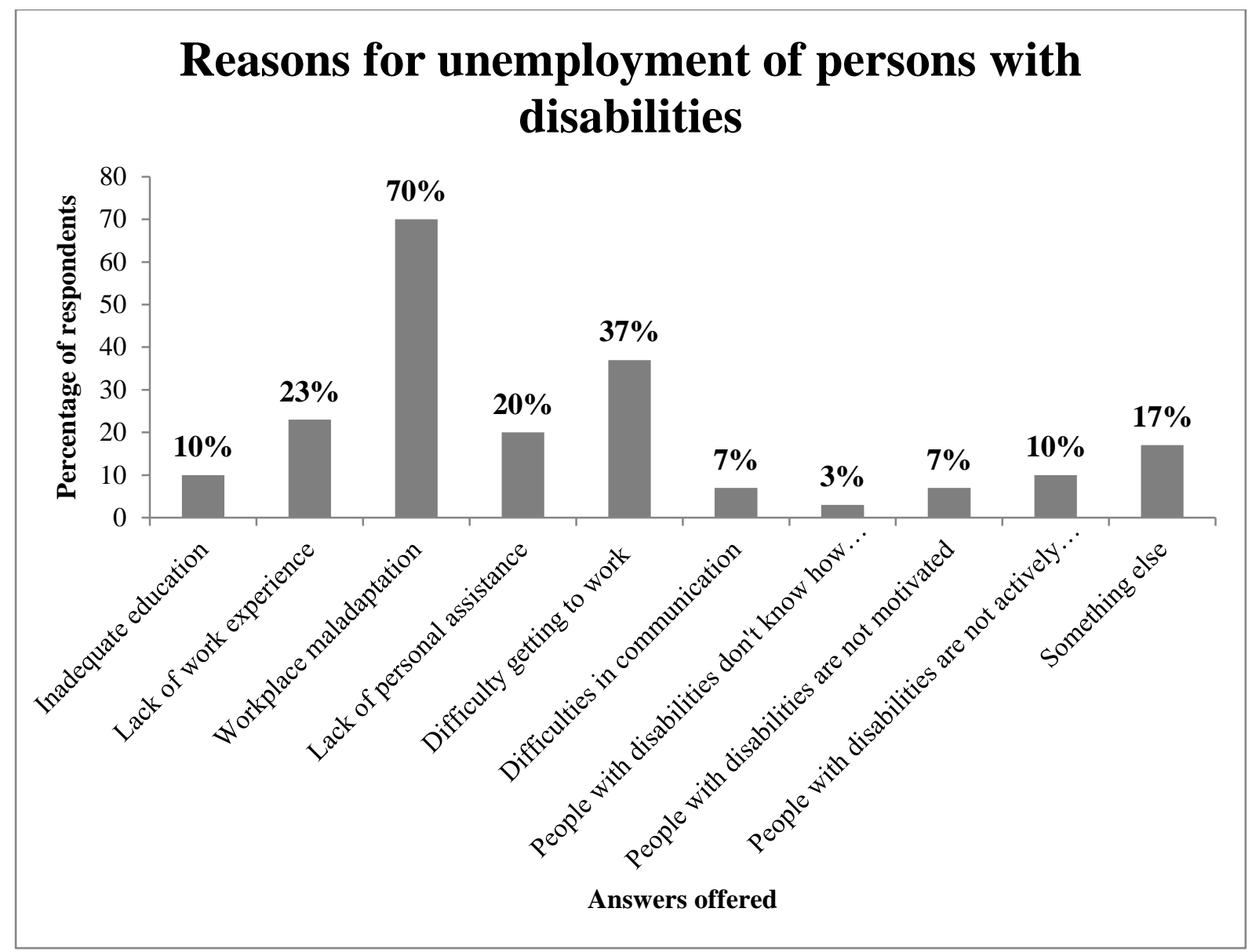

Graph 2. Reasons for unemployment of persons with disabilities

From this chart we can see that the highest percentage of employers $70 \%$ as the main reason for unemployment of persons with disabilities states job maladaptation, followed by difficulties in getting a job $37 \%$, then lack of work experience $23 \%$, inadequate education $10 \%$ while $3 \%$ surveyed employers state that the reason for unemployment is that people with disabilities do not know how to present themselves.

This research dealt with the perception of barriers to employment and work of persons with disabilities from the perspective of employers, such as the expected difficulties in employing this population, the interest and opportunities of employers themselves to employ persons with disabilities, the need for additional information on the professional abilities of these persons, as well as the most common reasons for unemployment in this category of the population. Given the size of the population, people with disabilities are considered the most populous minority and an untapped source of employment. Nevertheless, they very often experience negative socio-economic consequences in relation to people without disabilities, such as high unemployment rates, poverty, lower wages (Longhi, 2017). The most common causes of this situation are negative attitudes towards people with disabilities, concern about the costs of job adaptation, which was confirmed by our research (Chart 2), as well as concerns about productivity and legal responsibility. 
Although many employers consider the costs of job adaptation to be high, in practice these costs have been shown to be almost negligible, with many benefits for both disabled and nondisabled people (Australian Government, 2012). As one of the many advantages of workplace adaptation, we can say that the application of assistive technologies undoubtedly increases the productivity of people with disabilities, and also that the existence of elevators and adequate sloping planes, in addition to productivity, increases the mobility of employees without disabilities. In our research, as more one of the significant obstacles to the employment of persons with disabilities was the fact that most of the surveyed employers are interested in employing these persons, but that they have never applied such a practice in their company. One of the reasons is the lack of opportunities for employers to decide on this step and the lack of experience in contacts with people with disabilities. Another study shows that larger companies are more willing to employ people with disabilities and have more experience (Hanry et al, 2014). In contrast, small and medium companies are very often unaware of the resources and information that could be helpful in hiring people with disabilities. One in a series of obstacles is the lack of additional information on the capabilities of people with disabilities and the work tasks on which they can be engaged. In practice, it is not uncommon for people with disabilities not to accept the performance of the assigned tasks, with the explanation that they are not capable of them. Such cases and explanations of persons with disabilities can frustrate employers, who begin to wonder what are the work restrictions of persons with disabilities, ie. it is a matter of their will, and it is a matter of their abilities and capabilities, and how best they can engage them in carrying out the tasks for which they are capable. We believe that an adequate solution to this problem would be greater availability of support from vocational rehabilitation professionals, which would mean especially to employers who have not previously had experience with this type of employment. The research (Gelenčer, 2016) proved to be a successful strategy to nurture inclusive practices in companies, which means adapting and making available assistive technology that will be available to all employees, equal treatment of all employees, focus on work performance, not on disability as well as flexibility in work. In addition to all the above, it should be noted that employers who successfully employ people with disabilities have the ability to focus on the potential of the employee and thus can match the right person with a particular job. When employing this population, it is necessary to develop training programs for people with disabilities, to include job evaluation in order to determine which jobs people could work in depending on the type, degree and type of disability. Finally, it is necessary to determine with the person the time, scope and type of work he can perform (Bahtijarević-Šiber, 2014). Employment of people with disabilities can increase the competitiveness of companies in the market. It is considered that people with disabilities can contribute to the business of the company through a different perspective in work. One in a series of difficulties among employers is finding the necessary staff. Adequate education and / or work experience that employers require from new employees when recruiting new workers is often not in line with the labor market offer, especially when a number of healthy employees need to find people with disabilities that meet the employer's current needs. 
In addition to the problem of education, employers also recognized as a problem the fact that the support of the whole society is directed towards people with disabilities, something that contributes to their social integration, including employment. This support significantly affects the attitude of people with disabilities, their self-confidence and proactivity.

It is important to emphasize that the employers included in our research singled out the adaptation of the workplace and access to means of transport as one of the biggest obstacles. If we look at the level of education, we can say that employers are included in our survey of the opinion that it is not as important as the fact that people with disabilities can adequately respond to the demands of the job they are assigned to and that the work they perform is appropriate. their abilities.

People with disabilities should not be seen as less valuable because they, with adequate adaptation and adaptation of jobs, can perform work tasks on an equal footing with their colleagues without disabilities. However, in order to improve the position of persons with disabilities in the labor market, it is necessary to adequately apply legal regulations and legal acts, as well as work on achieving strategic directions of action.

\section{CONCLUSION}

Positive attitudes of employers towards the employment of people with disabilities open the door for the inclusion of these people in the labor market, but also more widely, in the life of the local community. However, regardless of the significant influence that employers have in the employment of people with disabilities, the responsibility for the successful employment of these people lies in their ability to work. There is a great need for employers for additional information on the employment opportunities of persons with disabilities on the one hand, while on the other hand it is necessary to educate employers on incentives for employment of these persons and the availability of equipment, aids and assistive technologies necessary for adaptation and adaptation with disabilities. Given the specifics of the existence of some form of disability, as well as the fact that people with disabilities face a large number of obstacles that contribute to their difficult employment, we believe that in order to improve the situation of this population in the labor market should work to raise awareness among both employers and the general population that people with disabilities can perform their tasks just as well as workers without disabilities, remove architectural barriers, develop a personal assistance service, provide tax relief for those employers who employ a large number of people with disabilities in their companies, which is provided by existing legal provisions. As a limiting factor that we encountered during this research, we can state that the research covered employers of state and private companies only in the city of Novi Sad, so the results can not be generalized to all employers in the Republic of Serbia. In order to gain a deeper insight into the attitudes or perspectives of employers regarding the employment of people with disabilities, it is important to take into account their first-hand experiences, as well as what worries them and what they feel insufficiently competent when a word on this subject. 
In this way, the circumstances and possible reasons that make it difficult for them to make decisions for the employment of persons with disabilities could be realistically considered, all with the aim of encouraging positive changes and improving the quality of support.

\section{LITERATURE}

1. Australian Government (2012). Improving the employment participation of people with disability in Australia. Australia: Australian Government.

2. Bahtijarević-Šiber, F. (2014). Strateški menadžment ljudskih potencijala: Suvremeni trendovi i izazovi. Zagreb: Školska knjiga.

3. Boni-Saenz, A. A., Heinemann, A. W., Crown, D. S., Emanuel, L. L. (2006). The Business of Employing People with Disabilities: Four Case Studies, Multi-Case Study Report.

4. Cvejić, S. (2013). Platforma za sindikalno organizovanje osoba sa invaliditetom-Izveštaj iz istraživanja položaj osoba sa invaliditetom na tržištu rada. Forum mladih sa invaliditetom: Beograd

5. Cvitanović, I., Gović - Penić, I., Novaković, N., Rismondo, M. (2015). Akutalnosti u radnim odnosima. Zagreb: Novi informator d.o.o.

6. Dimitrijević, B. (2016). Prepreke u zapošljavanju osoba sa telesnim invaliditetom u Srbiji. [doktorska disertacija, Univerzitet u Beogradu]. https://uvidok.rcub.bg.ac.rs/bitstream/handle/123456789/1736/Doktorat.pdf?sequence=1

7. Gelenčer, G. (2016). Imate li strategiju zapošljavanja osoba s invaliditetom? Preuzeto 15. novembra 2020, sa https://lider.media/aktualno/biznis-i-politika/hrvatska/imate-listrategiju-zaposljavanja-osoba-s-invaliditetom/

8. Gilbride, D., Stensrud, R., Vandergoot, D., Golden, K. (2003). Identification of the Characteristics of Work Environments and Employers Open to Hiring and Accommodating People with Disabilities. Rehabilitation Counseling Bulletin, 46(3):130137. https://psycnet.apa.org/doi/10.1177/00343552030460030101

9. Henry, A. D., Petkauskos, K., Stanislawzyk, J., Vogt, J. (2014). Employer-recommended strategies to increase opportunities for people with disabilities. Journal of Vocational Rehabilitation, 41(3):237-248. doi: 10.3233/JVR-140716

10. Houtenville, A., Kalargyrou, V. (2012). People with Disabilities: Employers' Perspectives on Recruitment Practices, Strategies, and Challenges in Leisure and Hospitality. Cornell Hospitality Quarterly, 53(1):40-52. doi: 10.1177/1938965511424151

11. Kaye, H. S., Jans, L. H., Jones, E. C. (2011). Why don't employers hire and retain workers with disabilities? Journal of occupational rehabilitation, 21(4):526-36. doi:10.1007/s10926-011-9302-8

12. Kiš-Glavaš, L., Skočić Mihić, S. (2010). Radna i socijalna kompetencija osoba s intelektualnim teškoćama. Razlozi poslodavcima za njihovo nezapošljavanje. Revija za socijalnu politiku, 3(17): 387-399. doi: 10.3935/rsp.v17i3.912

13. Lakićević, M. (2012.) Socijalna integracija osoba sa invaliditetom. Univerzitet u Beogradu: Fakultet političkih nauka.

14. Longhi, S. (2017). The disability pay gap. Equality and Human Rights Commission. Preuzeto 20. novemra 2020, sa https://equalityhumanrights.com/en/publicationdownload/research-report-107-disability-pay-gap/ 
15. Ljubinković, B., Zarić,G., Stanojević, M., Tatić, D., Janićijević, I. (2010). Zapošljavanje osoba sa invaliditetom u Srbiji- Mogućnosti i izazovi. Beograd: Centar za samostalni život invalida Srbije.

16. Nota, L., Santilli, S., Ginevra, M. C., Soresi, S. (2013). Employer Attitudes Towards the Work Inclusion of People With Disability. Journal of Applied Research in Intellectual Disabilities, 27(6): 511-520. https://doi.org/10.1111/jar.12081

17. Woodley, A., Metzger, N. (2012). Employer attitudes towards employing disabled people. Office for Disability Issues. Preuzeto 25. novemra 2020, sa https://www.odi.govt.nz/guidance-and-resources/employer-attitudes-toward-employingdisabled-people/

18. Young, J., Rosati, R., \& Vandergoot, D. (1986): Initiating a Marketing strategy By Assessing Employer Needs for Rehabilitation services. Joumal of Rehabilitati on, 52(2): $37-41$.

19. "Zakon o profesionalnoj rehabilitaciji i zapošljavanju osoba sa invaliditetom", Službeni glasnik Republike Srbije br. 36/2009. (2009).

20. Žuvela B. (2013). Individualni i kontekstualni činioci zapošljavanja slepih i slabovidih osoba. [doktorska disertacija, Univerzitet u Beogradu]. http://eteze.bg.ac.rs/application/showtheses?thesesId=956 